\title{
Evaluating the Influence of Deposition Conditions on Solvation of Reactive Conducting Polymers using Neutron Reflectivity
}

Andrew Glidle, Charlotte S. Hadyoon, Nikolaj Gadegaard, Jon M. Cooper, A. Robert Hillman*, Karl S.

Ryder, John R.P. Webster, Robert W. Wilson and Robert Cubitt

\section{SUPPORTING INFORMATION}

\begin{tabular}{|l|l|l|l|l|l|l|l|l|}
\hline $\begin{array}{l}{[\mathrm{PFP}]} \\
\text { solution } \\
/ \mathrm{mM}\end{array}$ & $\begin{array}{l}{[\mathrm{Py}]} \\
\text { solution / } \\
\mathrm{mM}\end{array}$ & $\begin{array}{l}\text { XPS at } \\
\text { solution } \\
\text { side } \\
\mathrm{F}(\text { atoms) } \\
\mathrm{N}(\text { atoms) }\end{array}$ & $\begin{array}{l}\text { \% PFP } \\
\text { units in } \\
\text { polymer- } \\
\text { solution } \\
\text { side }\end{array}$ & $\begin{array}{l}\text { \% Py } \\
\text { units in } \\
\text { polymer- } \\
\text { solution } \\
\text { side }\end{array}$ & $\begin{array}{l}\text { XPS at } \\
\text { electrode } \\
\text { side } \\
\mathrm{F} \text { (atoms)/ } \\
\mathrm{N} \text { (atoms) }\end{array}$ & $\begin{array}{l}\text { \% PFP } \\
\text { units in } \\
\text { polymer- } \\
\text { substrate } \\
\text { side }\end{array}$ & $\begin{array}{l}\text { \% Py } \\
\text { units in } \\
\text { polymer- } \\
\text { substrate } \\
\text { side }\end{array}$ & $\begin{array}{l}\text { 'Average' of } \\
\text { PFP units at } \\
\text { both } \\
\text { polymer } \\
\text { interfaces }\end{array}$ \\
\hline 10.0 & 0 & 5.02 & 100 & 0 & - & - & - & 100 \\
\hline 9.75 & 0.25 & 1.17 & 23.5 & 76.5 & 2.08 & 41.5 & 58.5 & 33.5 \\
\hline 9.50 & 0.50 & 0.72 & 14.5 & 85.5 & 1.04 & 20.8 & 79.2 & 17.5 \\
\hline 9.25 & 0.75 & 0.61 & 12.2 & 87.8 & 0.76 & 15.2 & 84.8 & 14 \\
\hline 9.00 & 1.00 & 0.67 & 13.5 & 86.5 & 0.68 & 13.6 & 86.4 & 13.6 \\
\hline 8.00 & 2.00 & 0.36 & 7.3 & 92.7 & - & - & - & 7.3 \\
\hline 5.00 & 5.00 & 0.13 & 2.6 & 97.4 & 0.13 & 2.61 & 97.4 & 2.6 \\
\hline
\end{tabular}

Table S1. Composition of PFP/Py copolymers determined by XPS for films deposited from 50\% $100 \%$ mole fraction of PFP in the deposition solution.

$\%$ PFP units in polymer film are determined from F/N XPS ratio using $\% \mathrm{PFP}=\mathrm{F}$ (atoms)/5N(atoms). Correlation of characteristic PFP and Py bands in RAIRS measurements of the above films with those in the films used in NR experiments is used to estimate the composition of the specific films used in the NR experiments (the physical size of the NR substrates prevents them being measured in the XPS instrument). 

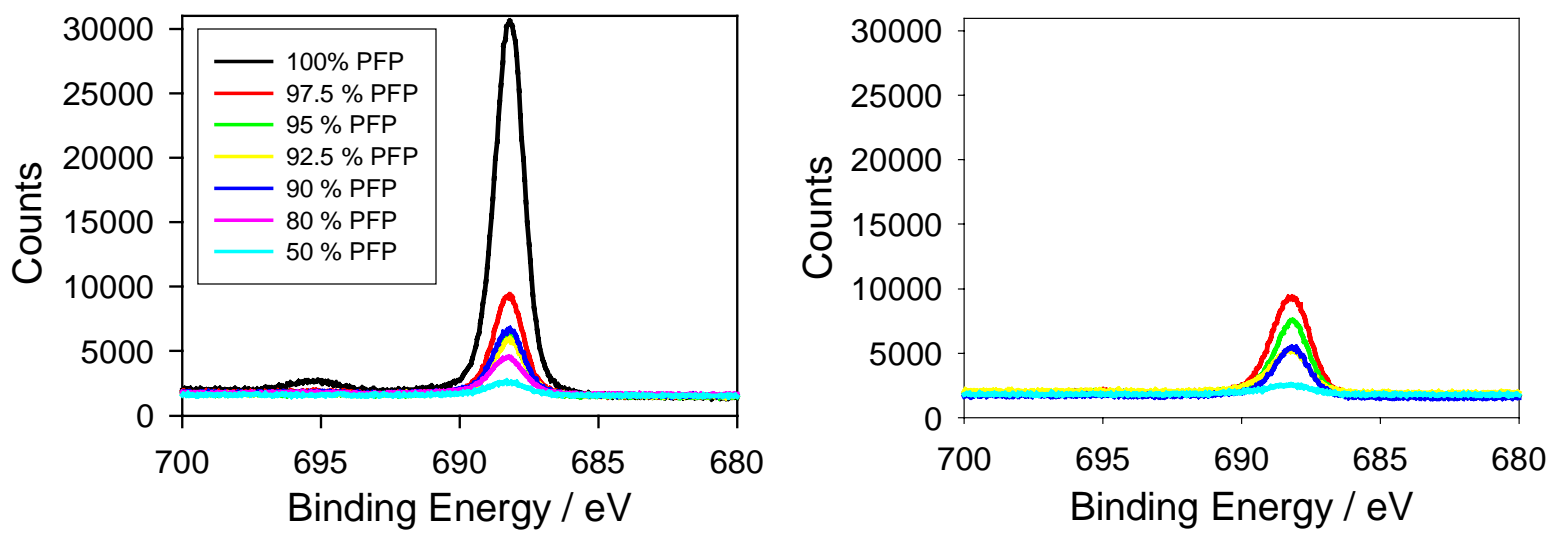

Fig. S1. F (1s) XPS spectra for poly(PFP) and poly(PFP/Py) copolymers corresponding to the data of Table S1. (a) Measurements of the polymer-solution interface (b) Measurements of the polymersubstrate interface. Broader linewidth $(\sim 2.1 \mathrm{eV}$ vs. $1.5 \mathrm{eV})$ of polymer-substrate interface spectra compared those of the polymer-solution interface is due to the former samples being supported by an insulating substrate (sticky tape) and the later samples being on a gold (conducting) electrode substrate. In both cases, a flood gun with identical parameters was used for charge compensation. 


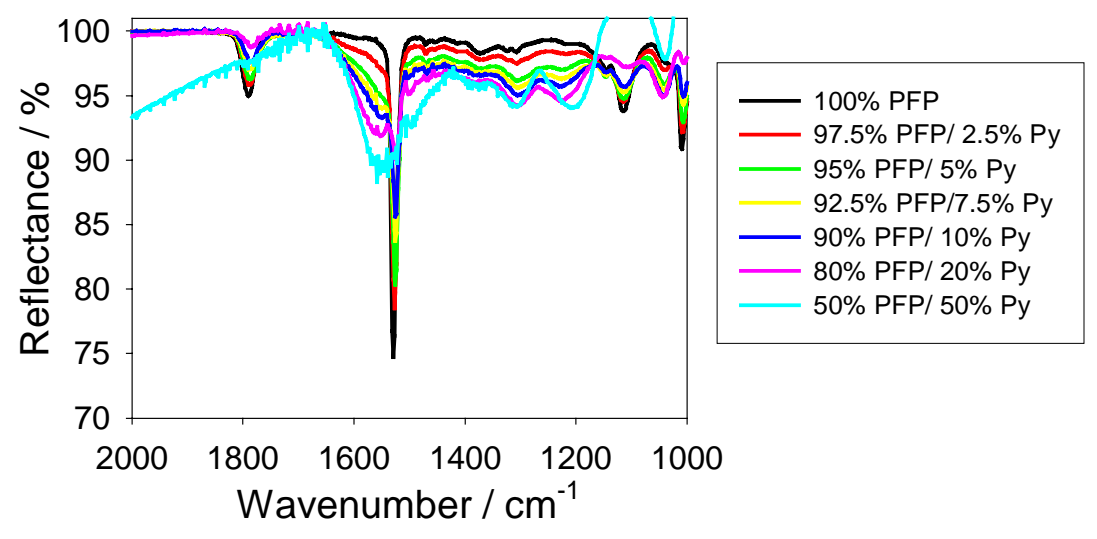

Fig. S2a. Reflectance FTIR spectra for homo poly(PFP) and poly(PFP/Py) copolymers of Fig. 6 (main text) before reaction with lysine. \% PFP and Py components in legend refer to deposition solution compositions. With the exception of that for the 50\% PFP/ 50\% Py film, all spectra show strong bands at $1790 \mathrm{~cm}^{-1}$ and $1520 \mathrm{~cm}^{-1}$ corresponding to the activated ester and pentrafluorophenyl ring respectively. The band at ca. $1550 \mathrm{~cm}^{-1}$ corresponds to the $\mathrm{N}-\mathrm{H}$ bending mode associated with the pyrrole ring. Comparison of activated ester and pentafluorophenyl bands in the spectra before and after reaction (main text, Fig. 6) show that the $100 \%$ PFP and $97.5 \%$ PFP/2.5\% Py films have undergone $<10 \%$ reaction after $24 \mathrm{~h}$ in the aqueous $\mathrm{pH} 9.5$ lysine solution, whereas for all the other films, the ester group has essentially reacted completely (a combination of aminolysis and hydrolysis). The sloping baseline in the spectrum of the 50\% PFP/ 50\% Py film above is associated with the near infra-red

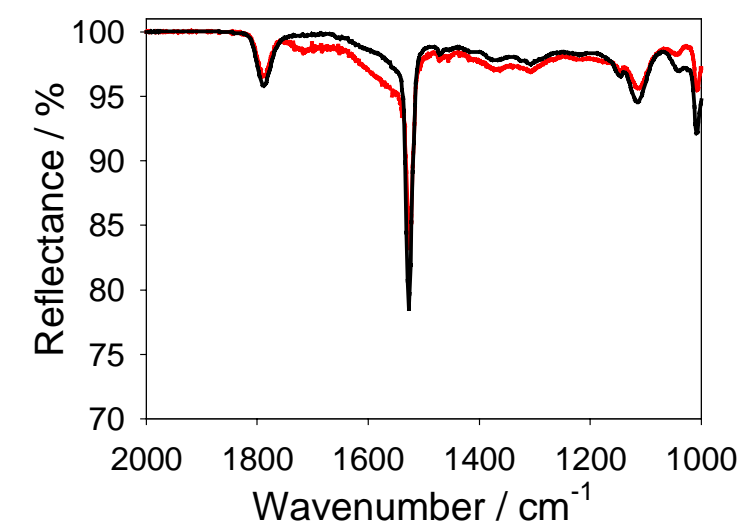

reflection-adsorption properties of doped poly(Py) films.

Figure S2b. Comparison of 33\%/67\% poly(PFP/Py) before (black) and after (red) reaction with $10 \mathrm{mM}$ lysine aqueous solution ( $\mathrm{pH} 9.5$ ) for $24 \mathrm{~h}$. This corresponds to a deposition solution with a monomer composition of $97.5 \% \mathrm{PFP}$ and $5 \% \mathrm{Py}$. Small change in peak at $1790 \mathrm{~cm}^{-1}$ corresponding to the activated ester group indicates that only a low level of reaction has occurred. The change in the shoulder at ca. $1600 \mathrm{~cm}^{-1}$ after immersion in the aqueous solution may reflect changes associated with the Pyrrole N-H bend due to interactions with either buffer ions or the small number of carboxylic acid 
groups generated during the immersion period (corresponding to a small peak at ca. $1710 \mathrm{~cm}^{-1}$ ). There are no discernable features at ca. $1640 \mathrm{~cm}^{-1}$ (which would correspond to amide groups) and so it cannot be determined whether the carboxylate peak at $1710 \mathrm{~cm}^{-1}$ is due to hydrolysis or immobilisation of lysine. 

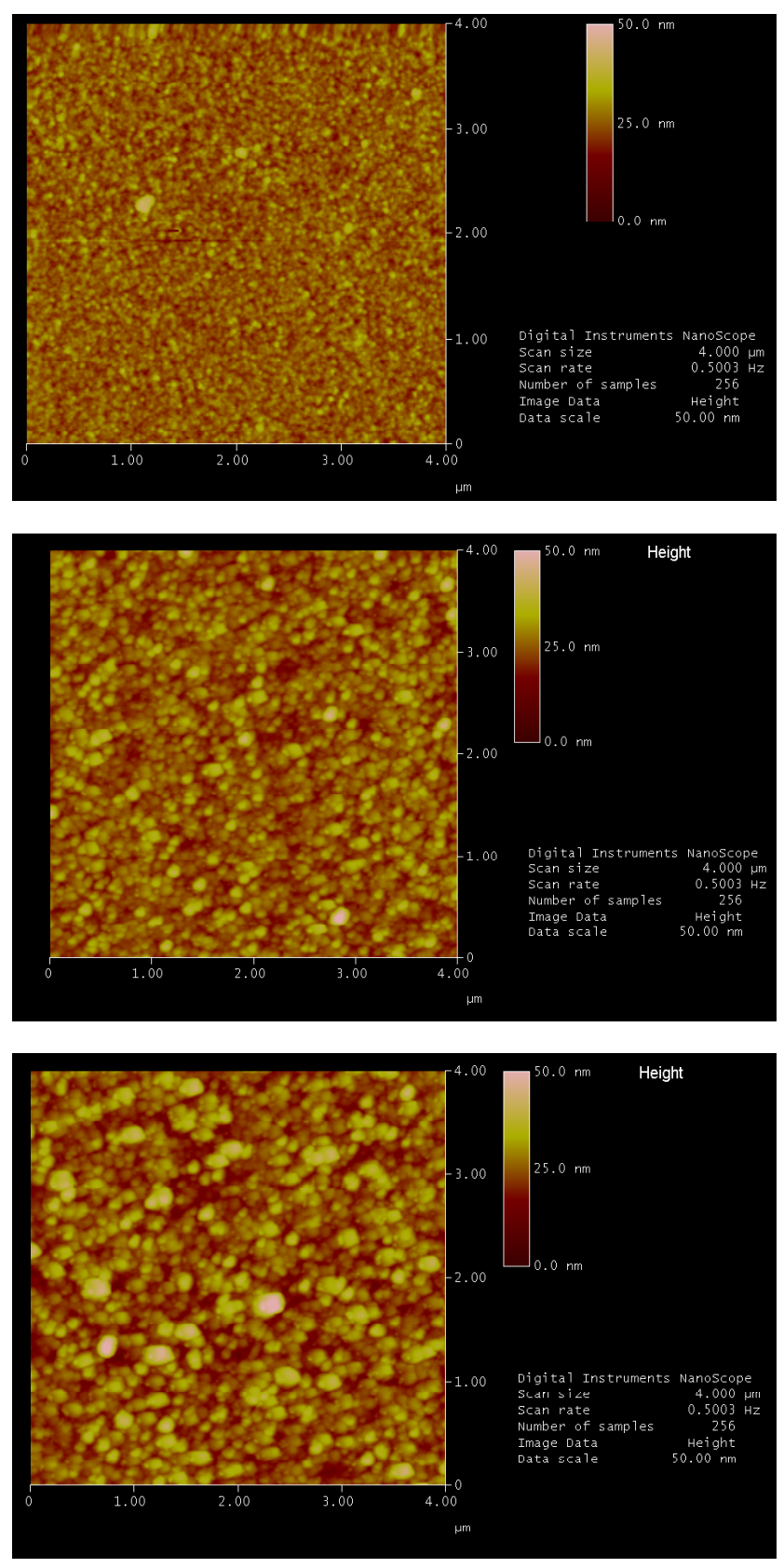

Early stage of slow deposited film (5 scans to $1.05 \mathrm{~V}$ ); roughness $2.39 \mathrm{~nm}$. Height scale 0 to $50 \mathrm{~nm}$.

Final stage of slow deposited film (15 scans to $1.05 \mathrm{~V}$ ); roughness $3.26 \mathrm{~nm}$. Height scale 0 to $50 \mathrm{~nm}$.

Final stage of fast deposited film (3 scans to $1.15 \mathrm{~V}$ ); roughness $4.22 \mathrm{~nm}$. Height scale 0 to $50 \mathrm{~nm}$.

Figure S3. AFM scans of 'fast' and 'slow' deposited poly(PFP) (dry) films deposited on evaporated gold film electrodes. Scan rate $20 \mathrm{mV} / \mathrm{s}$, potential limits $0.3 \mathrm{~V}$ to $1.05 \mathrm{~V}$ or $1.15 \mathrm{~V}$ as indicated. Solution 10 mM PFP/0.1 M TEAP/MeCN. $4 \square \mathrm{m} \mathrm{x} 4 \square \mathrm{m}$ AFM scans collected with a Digital instruments Nanoscope IIIa operating in tapping mode, 256 lines collected at a scan rate of $0.5 \mathrm{~Hz}$ 